\title{
Gabbroic to granitic crust formation at the Archaean-Proterozoic boundary and its metamorphic evolution, southern India
}

\author{
DURGALAKSHMI $^{1}$, I. S. WILLIAMS ${ }^{1}$, K. SAJEEV ${ }^{2}$
}

${ }^{1}$ Research School of Earth Sciences, Australian National University, durgalakshmi@anu.edu.au, ian.williams@anu.edu.au

${ }^{2}$ Centre for Earth Sciences, Indian Institute of Science, sajeev@iisc.ac.in

The Bhavani Complex in the Southern Granulite Terrane (SGT), southern India, is bounded by shear zones to the north and south. The Mesoarchaean Biligiri Rangan Hills, to the north of the complex, were metamorphosed at ca. $2.5 \mathrm{Ga}$. The terranes to the south of the complex have $2.5 \mathrm{Ga}$ protolith ages overprinted by 550 Ma metamorphism during the Pan African Orogeny. The Bhavani Complex itself, which formed at ca. 2.5 $\mathrm{Ga}$, is an ideal terrane to study the formation of the crust at the Archaean-Proterozoic boundary.

Zircon was extracted from four different rock types (felsic melt, granite, leuco gabbro, gabbro) found closely associated in the field to study the respective roles of source and differentiation in their formation, and to determine their subsequent metamorphic history. The SHRIMP zircon U-Pb ages of all rocks are similar: ca. $2.5 \mathrm{Ga}$ cores and ca. $800 \mathrm{Ma}$ rims. The $800 \mathrm{Ma}$ event is a newly-recognised metamorphism in the terrane. The $\delta^{18} \mathrm{O}$ of the various growth zones in zircon ranges from 6.2 to $7.5 \%$, suggesting either assimilation of supracrustal material into the magmas that formed the suite, or modification of the zircon oxygen isotopes during the $800 \mathrm{Ma}$ metamorphism. Zircon REE patterns are parallel for all rock types, suggesting they formed under similar conditions. The isochemical phase diagrams modelled using calcualted bulk chemical composition showing that the garnet-clinopyroxene bearing peak assemblage in gabbro was later overprinted by amphibole and ilmenite at a temperature above $940^{\circ} \mathrm{C}$ and pressure of ca.15 kbar. The mineral assemblage evolution indicates isothermal decompression associated with exhumation and hydration. That hydration can be linked to garnet breakdown reactions and overprinting of zircon associated with the ca. 800 Ma metamorphism.

Work is in progress to determine the sources of this diverse rock suite and to the determine the REE partitioning in other mineral phases in these rocks. 